\title{
Towards $12 \%$ stabilised efficiency in single junction polymorphous silicon solar cells: experimental developments and model predictions
}

\author{
Sergey Abolmasov ${ }^{1,2, a}$, Pere Roca i Cabarrocas ${ }^{2}$, and Parsathi Chatterjee ${ }^{2}$ \\ 1 R\&D Center of Thin-Film Technologies in Energetics, Ioffe Institute 28 Polytekhnicheskaya, 194064 Saint Petersburg, Russia \\ 2 LPICM, CNRS, Ecole Polytechnique, Université Paris-Saclay, 91128 Palaiseau, France
}

Received: 5 August 2015 / Received in final form: 30 November 2015 / Accepted: 11 December 2015 Published online: 26 January 2016

(C) Abolmasov et al., published by EDP Sciences, 2016

\begin{abstract}
We have combined recent experimental developments in our laboratory with modelling to devise ways of maximising the stabilised efficiency of hydrogenated amorphous silicon (a-Si:H) PIN solar cells. The cells were fabricated using the conventional plasma enhanced chemical vapour deposition (PECVD) technique at various temperatures, pressures and gas flow ratios. A detailed electrical-optical simulator was used to examine the effect of using wide band gap $\mathrm{P}$-and $\mathrm{N}$-doped $\mu \mathrm{c}-\mathrm{SiO}_{x}: \mathrm{H}$ layers, as well as a $\mathrm{MgF}_{2}$ anti-reflection coating (ARC) on cell performance. We find that with the best quality a-Si:H so far produced in our laboratory and optimised deposition parameters for the corresponding solar cell, we could not attain a $10 \%$ stabilised efficiency due to the high stabilised defect density of a-Si:H, although this landmark has been achieved in some laboratories. On the other hand, a close cousin of a-Si:H, hydrogenated polymorphous silicon (pm-Si:H), a nano-structured silicon thin film produced by PECVD under conditions close to powder formation, has been developed in our laboratory. This material has been shown to have a lower initial and stabilised defect density as well as higher hole mobility than a-Si:H. Modelling indicates that it is possible to attain stabilised efficiencies of $12 \%$ when pm-Si:H is incorporated in a solar cell, deposited in a NIP configuration to reduce the P/I interface defects and combined with P- and N-doped $\mu \mathrm{c}-\mathrm{SiO}_{x}: \mathrm{H}$ layers and a $\mathrm{MgF}_{2} \mathrm{ARC}$.
\end{abstract}

\section{Introduction}

Large-scale application of amorphous silicon based solar cells in the photovoltaic power generation industry requires improvement of their efficiency. Hydrogenated amorphous silicon (a-Si:H) based solar cells, in spite of their advantage of large area deposition, lag behind their crystalline counterparts with respect to conversion efficiency. Moreover they suffer from light-induced degradation, which can reduce cell efficiency by $\sim 25 \%$. Therefore much efforts have been made to develop growth conditions leading to a-Si:H based materials having improved transport properties or stability e.g. [1,2]. Also tandem or triple-junction solar cells, with thin, varying band gap materials in different sub-cells have been tried out and achieved an initial record efficiency of $16.3 \%$ [3]. This design improves light absorption over the entire visible spectrum and reduces light-induced degradation as it is possible here to use thinner sub-cells. However the design is

${ }^{\text {a }}$ e-mail: s.abolmasov@hevelsolar.com complex and it would be ideal technologically to attain a high stabilised efficiency in single junction solar cells. Moreover, this is a requisite for high stabilized efficiency in tandem and triple junction solar cells.

To this end, we have been experimenting with an a-Si:H-like material: hydrogenated polymorphous silicon (pm-Si:H), which is produced by the standard RF glow discharge decomposition of silane highly diluted in hydrogen, under conditions close to powder formation [4-8]. Pm-Si:H is a nano-structured silicon material with medium range order which shows up in the superior hole transport properties as deduced from diffusion induced time resolved microwave conductivity [8] and time-of-flight measurements [9]. Moreover it exhibits lower initial [5] and stabilised defect densities than standard a-Si:H $[1,9,10]$, with the $\eta \mu \tau$ product of electrons $200-$ 700 times higher than that of standard a-Si:H for samples in the as-deposited state [1], and attaining values after light-soaking comparable to those of standard a-Si:H films before degradation $[1,4-7]$. In reference [1], a comparative study has been made of the kinetics of defect creation in 

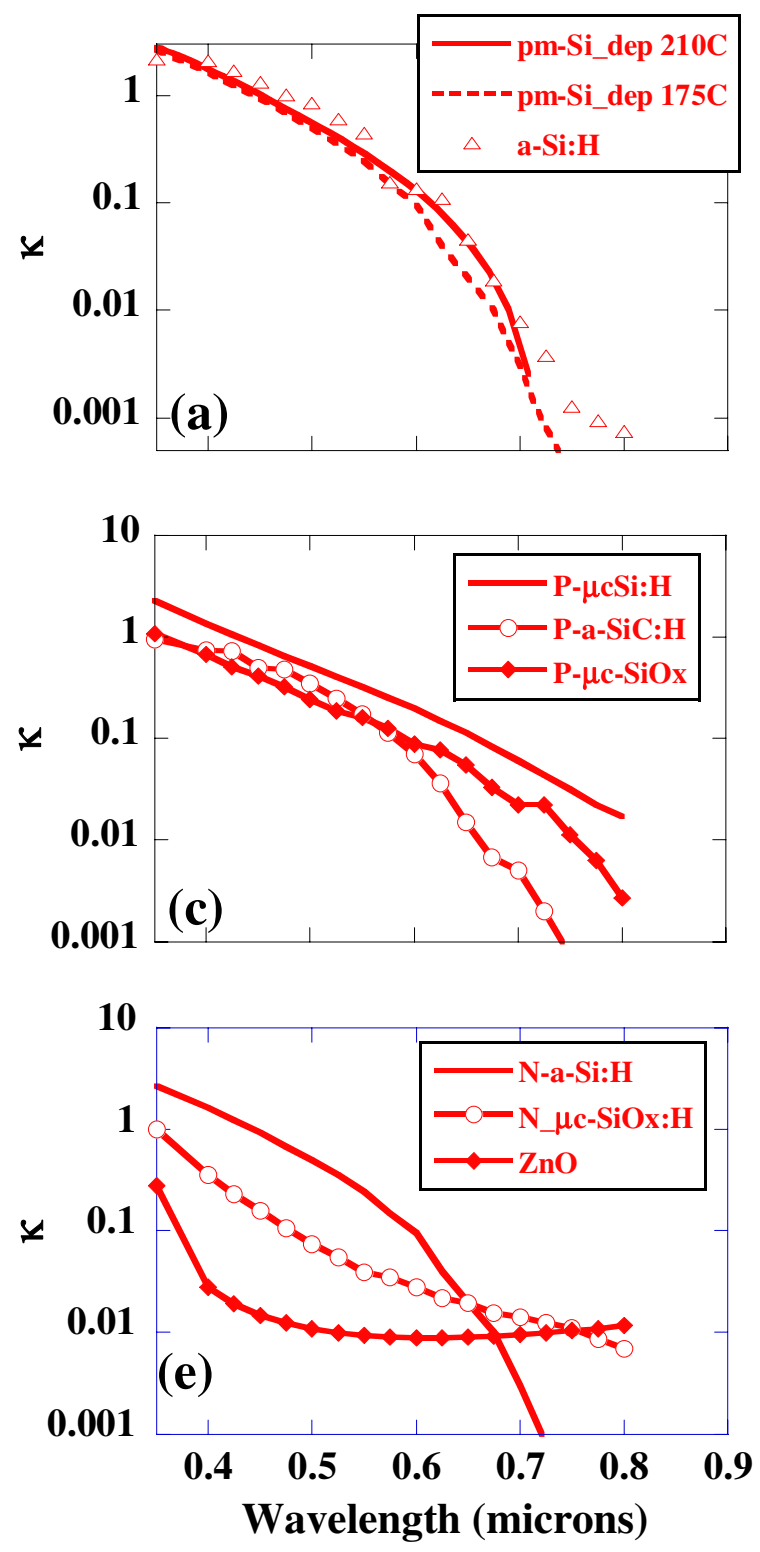
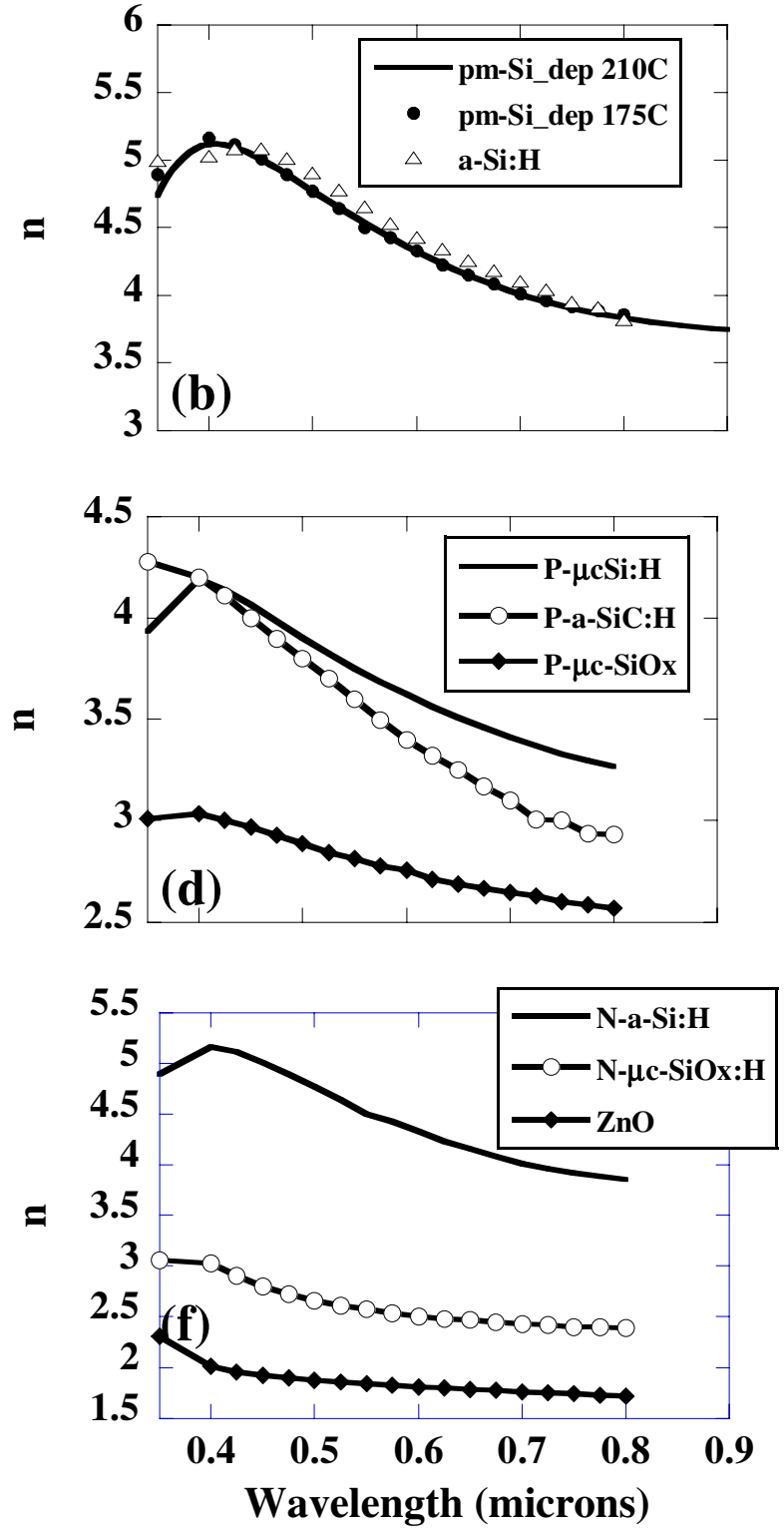

Fig. 1. Comparison of the complex refractive indices $(\kappa, n)(\mathrm{a})$ and $(\mathrm{b})$ of the intrinsic layers used in this study: a-Si:H, pm-Si:H deposited at $175{ }^{\circ} \mathrm{C}$ and $210{ }^{\circ} \mathrm{C} ;$ (c) and (d) of the various P-layers studied: $\mathrm{P}-\mu \mathrm{c}-\mathrm{Si}: \mathrm{H}, \mathrm{P}-\mathrm{a}-\mathrm{SiC}: \mathrm{H}$ and $\mathrm{P}-\mu \mathrm{c}-\mathrm{SiO}{ }_{x}: \mathrm{H} ;$ and $(\mathrm{e})$ and (f) of the different N-layers: N-a-Si:H, N- $\mu \mathrm{c}-\mathrm{SiO}_{x}: \mathrm{H}$ and the TCO: ZnO:Al.

standard a-Si:H and pm-Si:H films. It is found that the value of the absorption coefficient $\alpha(1.1 \mathrm{eV})$, obtained at 'saturation' is lower for the pm-Si:H than standard a-Si:H films, indicating a lower stabilized density of states (DOS) for the former case.

Unfortunately the material has slightly lower absorption coefficients than a-Si:H, therefore lower coefficients of extinction ( $\kappa-$ Fig. 1a) over the visible spectrum [11]. The wavelength dependence of the real part of the complex refractive indices (CRINDs) of pm-Si:H and a-Si:H are given in Figure 1b. Also in the same article [11], using detailed modelling to simulate the measured characteristics of solar cells fabricated with this material as the intrinsic layer, we have shown that pm-Si:H develops a very defective $\mathrm{P} / \mathrm{I}$ interface, probably due to bombardment by charged silicon nanocrystals contributing to the deposition and due to the high flux of hydrogen required to develop the material. Moreover other experiments performed at our laboratory [12] have shown that light-soaking of pm-Si:H leads to the formation of hydrogen bubbles that introduce macroscopic defects. In this article we show by modelling how the above drawbacks of a pm-Si:H solar cell can be overcome to produce solar cells with a high stabilised efficiency.

We have also tried out different window structures using modelling, to see which combination leads to the highest efficiency. Two types of front window designs, each with two P-layers were examined: (a) P- $\mu \mathrm{c}-\mathrm{Si}: \mathrm{H} / \mathrm{P}-$ a-SiC:H or (b) $\mathrm{P}-\mu \mathrm{c}-\mathrm{Si}: \mathrm{H} / \mathrm{P}-\mu \mathrm{c}-\mathrm{SiO}_{x}$. In a previous paper [13] modelling the effects of $\mathrm{P}-\mu \mathrm{c}-\mathrm{Si}: \mathrm{H}, \mathrm{P}-\mathrm{a}-\mathrm{SiC}: \mathrm{H}$ 
window layers and various combinations thereof, we have shown that a $\mathrm{P}-\mu \mathrm{c}-\mathrm{Si}: \mathrm{H} / \mathrm{P}-\mathrm{a}-\mathrm{SiC}: \mathrm{H}$ stack is an efficient design. Indeed, the $\mu \mathrm{c}-\mathrm{Si}: \mathrm{H}$ P-layer has a lower surface band bending (sbb) and lower activation energy than $\mathrm{P}-\mathrm{a}-\mathrm{SiC}: \mathrm{H}$. These properties help to improve the builtin potential $\left(V_{\mathrm{bi}}\right)$, open-circuit voltage $\left(V_{\mathrm{oc}}\right)$ and fill factor (FF) of solar cells employing such a double window layer structure relative to a standard cell having a single $\mathrm{P}-\mathrm{a}-\mathrm{SiC}: \mathrm{H}$ window layer [13]. These modelling results have received confirmation from the experimental work of $\mathrm{Ma}$ et al. [14]. The problem with a single $\mathrm{P}-\mu \mathrm{c}-\mathrm{Si}: \mathrm{H}$ window is the large valence band discontinuity, since it has been shown by the IPE measurements of Xu et al. [15] that the $\mathrm{P}-\mu \mathrm{c}-\mathrm{Si}: \mathrm{H} / \mathrm{a}-\mathrm{Si}: \mathrm{H}$ band discontinuity is almost totally on the valence band side. This fact results in a large drop in potential at the $\mathrm{P} / \mathrm{I}$ interface, leading to a collapse of the electric field inside the volume of the device and reducing the $V_{\mathrm{oc}}$ and the FF of a device employing such a single $\mathrm{P}-\mu \mathrm{c}-\mathrm{Si}: \mathrm{H}$ window. Also considerable back diffusion of electrons takes place, reducing the blue-green part of the external quantum efficiency (EQE) and shortcircuit current density $\left(J_{\mathrm{sc}}\right)$. In addition the $\mathrm{P}-\mu \mathrm{c}-\mathrm{Si}: \mathrm{H}$ layer developed in our laboratory has a higher coefficient of extinction (hence higher absorption coefficient) compared to $\mathrm{P}-\mathrm{a}-\mathrm{SiC}: \mathrm{H}$ or $\mathrm{P}-\mu \mathrm{c}-\mathrm{SiO}_{x}: \mathrm{H}$ over the visible solar spectrum, as seen from Figure 1c. A thin P-a-SiC:H buffer sandwiched between the $\mathrm{P}-\mu \mathrm{c}-\mathrm{Si}: \mathrm{H}$ and the a-Si:H layers solves all these problems, since the band discontinuity between a-Si:H and P-a-SiC:H is mainly on the conduction band side [16], preventing back diffusion of electrons and bringing up the short wavelength $\mathrm{QE}$ and $J_{\mathrm{sc}}$. Also, the detrimental effect of the large valence band discontinuity is reduced by the presence of a thin P-a-SiC:H layer [13], leading to high values of $V_{\mathrm{oc}}$ and FF. Moreover the presence of $\mathrm{P}-\mathrm{a}-\mathrm{SiC}: \mathrm{H}$, allows to use a thinner $\mathrm{P}-\mu \mathrm{c}-\mathrm{Si}: \mathrm{H}$ layer, so that the absorption of the shorter wavelengths in the $\mathrm{P}$-layers is reduced. $\mathrm{P}$-doped $\mu \mathrm{c}-\mathrm{SiO}_{x}: \mathrm{H}$ is also a promising $\mathrm{P}$-layer, since it is more transparent (having a wider band gap) than $\mathrm{P}-\mathrm{a}-\mathrm{SiC}: \mathrm{H}$ and its doping density can be adjusted to yield high conductivity. We have in this study therefore also tried out by modelling a $\mathrm{P}-\mu \mathrm{c}-\mathrm{Si}: \mathrm{H} / \mathrm{P}-\mu \mathrm{c}-$ $\mathrm{SiO}_{x}: \mathrm{H}$ double window structure, primarily because we know the TCO/P sbb for the case of P- $\mu$ c-Si:H [14], but it is unknown in the case of $\mathrm{P}-\mu \mathrm{c}-\mathrm{SiO}_{x}: \mathrm{H}$. Nevertheless we have also experimented with a single $\mathrm{P}-\mu \mathrm{c}-\mathrm{SiO}_{x}: \mathrm{H}$ window layer, assuming a range of values for the $\mathrm{ZnO}: \mathrm{Al} / \mathrm{P}-\mu \mathrm{c}-$ $\mathrm{SiO}_{x}: \mathrm{H}$ sbb. In all cases an ultra-thin intrinsic buffer layer follows the window $\mathrm{P}$ layers, both to prevent boron tailing into the intrinsic layer and to obtain a less defective P/I interface.

Different back contact designs were also investigated via modelling. This was either $\mathrm{N}-\mathrm{a}-\mathrm{Si}: \mathrm{H} / \mathrm{ZnO}: \mathrm{Al} / \mathrm{Ag}$ or simply $\mathrm{N}-\mu \mathrm{c}-\mathrm{SiO}_{x}: \mathrm{H} / \mathrm{Ag}$ with the $\mathrm{ZnO}: \mathrm{Al}$ left out. The logic behind this latter design is that the band gap and doping density of $\mathrm{N}-\mu \mathrm{c}-\mathrm{SiO}_{x}: \mathrm{H}$ can be adjusted in such a way that it can be used as a wide band gap TCO, while retaining a good enough conductivity to act as the N-layer of the cell [17]. Thus the deposition of an extra TCO layer can be avoided. However this is only possible in cases where the P-layer is deposited first on $\mathrm{ZnO}: \mathrm{Al}$ coated glass. When a cell is deposited in a NIP configuration, a thin $\mathrm{ZnO}: \mathrm{Al}$ layer between the silver and $\mathrm{N}-\mu \mathrm{c}-\mathrm{SiO}_{x}: \mathrm{H}$ is mandatory to prevent silver diffusion into the latter. The CRIND's of $\mathrm{N}-\mu \mathrm{c}-\mathrm{SiO}_{x}: \mathrm{H}$ are compared to those of standard N-a-Si:H and the TCO ZnO:Al in Figures 1e and 1f. Finally we have used modelling to study how a thin anti-reflection coating (ARC), deposited on the surface through which light enters the solar cell, can affect $J_{\mathrm{sc}}$ (and hence the conversion efficiency $\eta$ ).

In brief, the aim of this article is to use the measured values of the initial and stabilised state properties of the best a-Si:H and pm-Si:H materials developed in our laboratory so far, together with realistic $\mathrm{P} / \mathrm{I}$ interface defect density and other properties extracted by modelling the corresponding solar cells in an earlier article [11], combined with different emitter and N-layer materials and designs, to predict using modelling the highest efficiency attainable in these structures. We find, using the material and deposition parameters of our a-Si:H solar cells, that it is difficult to attain $10 \%$ stabilised efficiency with this material, even though other laboratories e.g. [18] have actually developed a-Si:H single junction cells with stabilised efficiencies in excess of $10 \%$. This is likely due to the superior nature and/or light absorption of the a-Si:H material developed, improved P/I interface properties in their deposited solar cells, etc. On the other hand we have been able to develop pm-Si:H $[1,4-8]$, a close cousin of a-Si:H, with lower initial and stabilised defect densities, higher hole mobility, but lower light absorption. Using modelling we show in this article that such a material when deposited in a solar cell in the NIP configuration, and in conjunction with suitable P- and N-layers and an ARC is capable of attaining a stabilised efficiency of around $12 \%$, although our best experimental results so far show a lower stabilised efficiency [19].

Schematic diagrams of the a-Si:H solar cell deposited in a PIN configuration on TCO-coated glass, and of the pm-Si:H cell deposited in a NIP configuration on glass/ $\mathrm{Ag} / \mathrm{ZnO}: \mathrm{Al}$ are shown in Figures $2 \mathrm{a}$ and $2 \mathrm{~b}$, respectively. These are the structures that have been modelled. It would have been better if the ARC were assumed to be textured also; however as will be pointed out in the section on the simulation model ASDMP, this latter at present is capable of handling only two textured interfaces. These have been taken at the $\mathrm{TCO} / \mathrm{P}$ and $\mathrm{N} /$ back reflector $(\mathrm{ZnO}: \mathrm{Al} / \mathrm{Ag}$ or only $\mathrm{Ag})$ interface to maximise light absorption in the intrinsic layer, except when $\mu \mathrm{c}-\mathrm{SiO}_{x}: \mathrm{H}$ is used as the N-layer. The refractive index of this N-layer is close to that of $\mathrm{ZnO}: \mathrm{Al}$, so that most of the light in reality suffers specular and diffused reflection at the $\mathrm{I} / \mathrm{N}-\mu \mathrm{c}-\mathrm{SiO}_{x}: \mathrm{H}$ interface. Hence it is this latter interface that is taken as the second textured interface in the modelling calculations. The layers between the top TCO and bottom reflector are thin and we assume that they almost exactly take up the structure of the preceding layer (conformal deposition). Therefore we have assumed that only specular reflection, obeying Fresnel's law, takes place at these interfaces. 
(a)

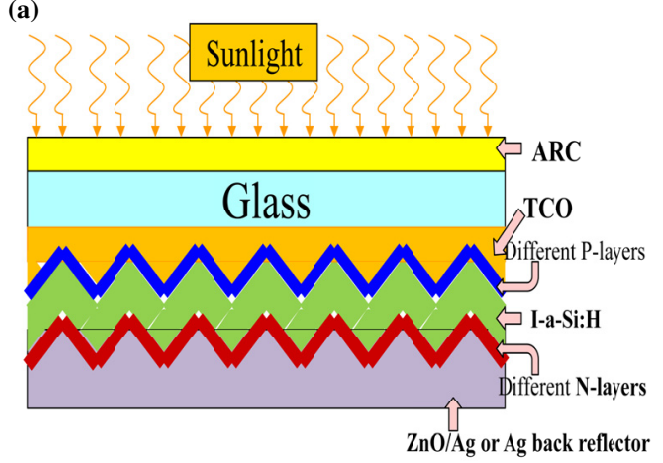

(b)

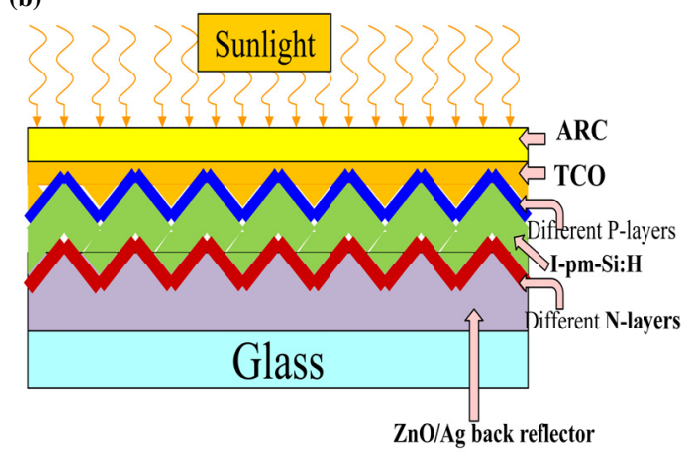

Fig. 2. Schematic representations of (a) an a-Si:H solar cell (deposited in the PIN configuration on TCO coated glass) and (b) a pm-Si:H solar cell deposited in the NIP configuration on $\mathrm{TCO} / \mathrm{Ag}$ coated glass.

\section{Experiments}

The PIN devices were deposited at various temperatures ranging from $175{ }^{\circ} \mathrm{C}$ to $240{ }^{\circ} \mathrm{C}$ by the $\mathrm{RF}$ $(13.56 \mathrm{MHz})$ glow discharge plasma enhanced chemical vapor deposition (PECVD) method in a multiplasmamonochamber reactor [20]. Standard a-Si:H films were produced by the dissociation of pure silane at $40 \mathrm{mTorr}$ under an RF power of $10 \mathrm{~mW} / \mathrm{cm}^{2}$. On the other hand, pm-Si:H films were obtained by the dissociation of a $10 \%$ silane in hydrogen mixture at 2-4 Torr under an RF power of $90 \mathrm{~mW} / \mathrm{cm}^{2}$. A deposition rate of $9 \AA / \mathrm{s}$ could be achieved for the pm-Si:H films [21]. We experimented with two different deposition temperatures $\left(175^{\circ} \mathrm{C}\right.$ and $210{ }^{\circ} \mathrm{C}$ ), but were unable to obtain any significant increase in the absorption coefficients in the case of a-Si:H. However for pm-Si:H, a substrate temperature of $210^{\circ} \mathrm{C}$ allowed to obtain films with a higher absorption over the visible wavelengths than for $\mathrm{pm}-\mathrm{Si}: \mathrm{H}$ deposited at $175^{\circ} \mathrm{C}$. The CRINDs of a-Si:H, and pm-Si:H deposited at two different temperatures are compared in Figures 1a and 1b.

The a-Si:H PIN cells were deposited in the conventional structure: glass/ZnO: $\mathrm{Al} / \mathrm{P} / \mathrm{I} / \mathrm{N} / \mathrm{ZnO}: \mathrm{Al} / \mathrm{Ag}$ (or simply Ag back eflector) (Fig. 2a). However it has been shown in a previous article [11] combining modelling with experiments, that a pm-Si:H intrinsic layer cell deposited in this order develops a very damaged $\mathrm{P} / \mathrm{I}$ interface due to bombardment by the high dose of hydrogen required for developing pm-Si:H. Other experiments conducted in our laboratory [12] further highlight that upon light-soaking treatments, hydrogen bubbles form and lead to macroscopic defects, such as blisters and delamination, that obviously cannot be reversed by annealing. Therefore, as we are interested in the stabilised efficiency, we have modelled pm-Si:H cells with the material deposited as follows: glass/silver/ZnO:Al/N/I/P/ZnO:Al/silver grid in that order (Fig. 2b). The high flux of hydrogen required for pmSi:H deposition will then damage the N/I interface, to which, as will be shown later by modelling, the solar cell output is much less sensitive. Also macroscopic defects, if any, will now appear at the $\mathrm{ZnO}: \mathrm{Al} / \mathrm{N}$ contact and will therefore have far less repercussion on solar cell characteristics. The light of course should still enter through the P-layer during cell operation for improved efficiency, since the maximum number of holes needs to be created near the contact that is the collector of holes (the $\mathrm{ZnO}: \mathrm{Al} / \mathrm{P}$ contact in this case). This is because, even though the mobility of holes in pm-Si:H is a factor of 3 higher than that in a-Si:H $[8,9]$, it is still less than the electron mobility. The a-Si:H PIN cell does not have a very damaged P/I interface [11], since this material can be deposited by the decomposition of $\mathrm{SiH}_{4}$ without or very little hydrogen dilution. We therefore commence the investigations in this article on a-Si:H PIN cells, deposited in the normal manner with the P-layer first on $\mathrm{ZnO}: \mathrm{Al}$ coated glass; but pm-Si:H cells deposited with N-layer first on glass/silver/ZnO:Al. For any deposition involving a rich hydrogen environment, $\mathrm{ZnO}$ is preferable to either ITO or $\mathrm{SnO}_{2}$, as $\mathrm{ZnO}$ is more stable against reduction by atomic hydrogen. The RMS roughness of the LPCVD grown $\mathrm{ZnO}: \mathrm{Al}$ is around $60 \mathrm{~nm}$ corresponding to a haze of $\sim 23 \%$, measured at a wavelength of $550 \mathrm{~nm}$.

To attain the stabilised state, the samples were light soaked at $100{ }^{\circ} \mathrm{C}$ in order to accelerate the kinetics of creation of metastable defects [22]. They were exposed to a maximum intensity of $670 \mathrm{~mW} \mathrm{~cm}^{-2}$ unfiltered white light produced by a $1 \mathrm{~kW}$ halogen lamp and then quenched to $30{ }^{\circ} \mathrm{C}$ for their characterisation [1]. In some other lightsoaking (LS) experiments [19], the cells were light soaked in the open-circuit condition using a mercury vapour lamp providing an intensity of $100 \mathrm{~mW} / \mathrm{cm}^{2}$. During LS, the cells were fan-cooled to reduce illumination-induced heating. The temperature of the cells was monitored using a PT100 thermocouple during LS, to verify that the device temperature remained under $50{ }^{\circ} \mathrm{C}$. Light-soaking was continued for $500 \mathrm{~h}$.

P- $\mu$ c-Si:H, P-a-SiC:H and P- $\mu$ c-SiO $x$ layers have also been developed in our laboratory with properties given in Table 1 . The values given in the table are representative of a series of each such film grown under the same conditions. The CRIND's of the P-layers are compared in Figures $1 \mathrm{c}$ and $1 \mathrm{~d}$. The conductivity of our $\mathrm{P}-\mu \mathrm{c}-\mathrm{SiO}_{x}$ films is strongly dependent on the $\mathrm{CO}_{2}$ flow rate [23], nevertheless, its conductivity compares well with that of optimised $\mathrm{P}-\mathrm{aSiC}: \mathrm{H}$ layers. The properties of the $\mathrm{N}-\mu \mathrm{c}-\mathrm{SiO}_{x}$ have however been taken from reference [17] and its CRIND's are compared to those of standard N-a-Si:H and the TCO $\mathrm{ZnO}: \mathrm{Al}$ in Figures 1e and 1f. 
Table 1. The input parameters used to model different cases. The first $5 \mathrm{~nm}$ of the I-pm-Si:H layer at the N/I interface has a DB DOS of $5 \times 10^{17} \mathrm{~cm}^{-3}$, followed by a $30 \mathrm{~nm}$ intermediate layer with a DOS $=2 \times 10^{16} \mathrm{~cm}^{-3}$. The first $20 \mathrm{~nm}$ of the I-a-Si:H layer adjacent to the P/I interface is assumed to have a DOS of $2 \times 10^{16} \mathrm{~cm}^{-3}$. The values have been extracted from modelling previous experimental results [11]. The parameters of N-a-Si:H are not shown as these are standard.

\begin{tabular}{|c|c|c|c|c|c|c|}
\hline Parameter & $\mathrm{P}-\mu \mathrm{c}-\mathrm{Si}: \mathrm{H}$ & P-a-SiC:H & $\mathrm{P}-\mu \mathrm{c}-\mathrm{SiO}_{x}$ & $\mathrm{~N}-\mu \mathrm{cSiO} x$ & I-pm-Si:H & I-a-Si:H \\
\hline Layer thickness (nm) & 6 & 4 & 10 & 10 & 250 & $200-300$ \\
\hline Electron affinity $(\mathrm{eV})$ & 4.00 & 3.89 & 3.67 & 4.00 & 3.95 & 4.00 \\
\hline Mobility gap (eV) & 1.6 & 2.0 & 2.5 & 2.4 & 1.96 & 1.84 \\
\hline Activation energy $(\mathrm{eV})$ & 0.12 & 0.46 & 0.47 & 0.09 & 0.92 & 0.86 \\
\hline Eff. DOS in bands $\left(\mathrm{cm}^{-3}\right)$ & $2 \times 10^{20}$ & $2 \times 10^{20}$ & $2 \times 10^{20}$ & $2 \times 10^{20}$ & $2 \times 10^{20}$ & $2 \times 10^{20}$ \\
\hline Ch Energy (VB tail) $(\mathrm{eV})$ & 0.035 & 0.120 & 0.120 & 0.025 & 0.050 & 0.050 \\
\hline Ch Energy (CB tail) $(\mathrm{eV})$ & 0.025 & 0.07 & 0.070 & 0.015 & 0.030 & 0.030 \\
\hline$\mu_{n}\left(\mu_{p}\right)\left(\mathrm{cm}^{2} / \mathrm{V} \mathrm{s}\right)$ & $32(8)$ & $20(4)$ & $32(8)$ & $32(8)$ & $20(12)$ & $20(4)$ \\
\hline $\operatorname{DOS}\left(\mathrm{cm}^{-3}\right)$ (annealed) & $3 \times 10^{18}$ & $3 \times 10^{18}$ & $4 \times 10^{18}$ & $2 \times 10^{18}$ & $7 \times 10^{14}$ & $5 \times 10^{15}$ \\
\hline DOS $\left(\mathrm{cm}^{-3}\right)$ (stabilized) & $3 \times 10^{18}$ & $3 \times 10^{18}$ & $4 \times 10^{18}$ & $2 \times 10^{18}$ & $2 \times 10^{16}$ & $10^{17}$ \\
\hline$\sigma_{n}($ tails $)\left(\mathrm{cm}^{2}\right)$ & $10^{-17}$ & $10^{-17}$ & $10^{-17}$ & $10^{-17}$ & $10^{-17}$ & $10^{-16}$ \\
\hline$\sigma_{c}($ tails $)\left(\mathrm{cm}^{2}\right)$ & $10^{-16}$ & $10^{-16}$ & $10^{-16}$ & $10^{-15}$ & $10^{-15}$ & $5 \times 10^{-16}$ \\
\hline$\sigma_{n}(\mathrm{DB})\left(\mathrm{cm}^{2}\right)$ (annealed) & $10^{-16}$ & $10^{-16}$ & $10^{-16}$ & $5 \times 10^{-17}$ & $10^{-15}$ & $10^{-16}$ \\
\hline$\sigma_{c}(\mathrm{DB})\left(\mathrm{cm}^{2}\right)($ annealed $)$ & $5 \times 10^{-16}$ & $5 \times 10^{-16}$ & $5 \times 10^{-16}$ & $5 \times 10^{-15}$ & $5 \times 10^{-15}$ & $5 \times 10^{-16}$ \\
\hline$\sigma_{n}(\mathrm{DB})\left(\mathrm{cm}^{2}\right)$ (stabilized) & $10^{-16}$ & $10^{-16}$ & $10^{-16}$ & $5 \times 10^{-17}$ & $10^{-15}$ & $2 \times 10^{-16}$ \\
\hline$\sigma_{c}(\mathrm{DB})\left(\mathrm{cm}^{2}\right)($ stabilized $)$ & $5 \times 10^{-16}$ & $5 \times 10^{-16}$ & $5 \times 10^{-16}$ & $5 \times 10^{-15}$ & $2 \times 10^{-14}$ & $2 \times 10^{-14}$ \\
\hline
\end{tabular}

\section{Simulation model}

Our one-dimensional electrical-optical model ASDMP (Amorphous Semiconductor Device Modelling Programme) [24,25], later extended to model crystalline silicon and HIT cells [26], solves the Poisson's equation and the two carrier continuity equations under steady state conditions for the given device structure and yields the dark and illuminated current density-voltage $(J-V)$ characteristics and the QE. The electrical part of the modelling programme is described in references $[27,28]$. The expressions for the free and trapped charges, the recombination term, the boundary conditions and the solution technique in ASDMP are similar to the AMPS computer programme [29], developed by Prof. Fonash's group.

The gap state model in ASDMP consists of two monovalent donor-like and acceptor-like tail states and two monovalent Gaussian distribution functions (one being of donor type and the other of acceptor type) to simulate the deep dangling bond (DB) states (as e.g. used in [29] (AMPS), [30,31] (AFORS-HET)). A more realistic gap state distribution model in a-Si:H would consist of, besides the monovalent band tail states, a deep defect distribution of DBs determined from the defect pool model (DPM) $[32,33]$. However in ASDMP, as in AMPS and AFORS-HET, since only monovalent states can be introduced, the deep DB distribution determined from DPM is replaced by two Gaussian distributions of monovalent states, donor like and acceptor like, separated by a correlation energy. Such a replacement has proved to be quite accurate in a-Si:H $[34,35]$.

The contact barrier heights for a cell with the P-layer in contact with a TCO at $x=0$ and the N-layer in contact with a TCO or metal at $x=L$, are given by:

$$
\varphi_{B 0}=E_{\mu}(P)-E_{a c}(P)-s b b
$$

and

$$
\varphi_{B L}=E_{a c}(N) .
$$

Here $E_{\mu}(P)$ and $E_{a c}(P)$ are the mobility gap and the activation energy of the P-layer, and $E_{a c}(N)$ is the activation energy of the N-layer, forming an ohmic contact at the back of the device. 'sbb' is the TCO/P surface band bending, which we have taken to be $\sim 0.16 \mathrm{eV}$, the measured value [14] for this quantity for P- $\mu \mathrm{c}-\mathrm{Si}: \mathrm{H}$, employed in all double window structures. A value of $0.2 \mathrm{eV}$ has been assumed for $\mathrm{P}-\mu \mathrm{c}-\mathrm{SiO}_{x}: \mathrm{H}$, in simulations involving such a single P-layer. However, later in Section 4 we show the effect of varying the sbb $\left(\mathrm{P}-\mu \mathrm{c}-\mathrm{SiO}_{x}: \mathrm{H}\right)$ on the solar cell output. With the activation energies and mobility band gaps of $\mathrm{P}-\mu \mathrm{c}-\mathrm{Si}: \mathrm{H}$ and $\mathrm{P}-\mu \mathrm{c}-\mathrm{SiO}_{x}: \mathrm{H}$ given in Table 1 , $\varphi_{\mathrm{B} 0}$ in the present PIN devices is $1.32 \mathrm{eV}$ in the case of TCO/P- $\mu \mathrm{c}-\mathrm{Si}: \mathrm{H}$ and $1.83 \mathrm{eV}$ for TCO $/ \mathrm{P}-\mu \mathrm{c}-\mathrm{SiO}_{x}: \mathrm{H} . \varphi_{\mathrm{BL}}$ is $0.2 \mathrm{eV}$ for the case of N-a-Si:H and $0.09 \mathrm{eV}$ for N- $\mu \mathrm{c}-$ $\mathrm{SiO}_{x}: \mathrm{H}[19]$.

The generation term in the continuity equations has been calculated using a semi-empirical model [36] that has been integrated into the modelling programme $[24,25]$. Both specular interference effects and diffused reflectances and transmittances due to the interface roughness are taken into account. As mentioned earlier, in the model it is possible to consider only two rough interfaces. The diffused reflection and transmission from the TCO ( $\mathrm{ZnO}: \mathrm{Al})$ used in the simulations have both a wavelength and angular dependence. In some of the simulations the effect of using a $\mathrm{MgF}_{2} \mathrm{ARC}$ is given. This layer is assumed to have a thickness of $50 \mathrm{~nm}$ - however it was not optimised by changing its thickness. The complex refractive index for 
Table 2. Sensitivity of a pm-Si:H solar cell output to a damaged N/I and a similarly damaged P/I interface (modelling results). The cells given here have a two P-layer structure with light entering the device on the P-layer side.

\begin{tabular}{cccccc}
\hline $\begin{array}{c}\text { ZnO:Al } / \mathrm{P}-\mu \mathrm{c}-\mathrm{Si} / \mathrm{P}-\mu \mathrm{c}-\mathrm{SiO} \\
\text { N- } / \mathrm{I}-\mathrm{pm}-\mathrm{Si}: \mathrm{H} /\end{array}$ & $J_{\mathrm{sc}}\left(\mathrm{mA} \mathrm{cm}^{-2}\right)$ & $V_{\mathrm{oc}}($ volts $)$ & FF & $\begin{array}{c}\text { Efficiency } \\
(\%)\end{array}$ \\
\hline With a damaged N/I interface & Initial & 15.29 & 1.140 & 0.772 & 13.45 \\
& Stabilised & 15.15 & 1.073 & 0.701 & 11.40 \\
\hline With a damaged P/I interface & Initial & 15.41 & 1.063 & 0.665 & 10.90 \\
& Stabilised & 15.26 & 1.044 & 0.608 & 9.69 \\
\hline
\end{tabular}

each layer of the structure is required as input and has been measured in-house by spectroscopic ellipsometry. In all cases studied in this article, experimentally or by modelling, light enters through the P-layer, the junction of the TCO with the P-layer being taken as $x=0$ on the position scale in the modelling calculations. Voltage is also applied at $x=0$, with the $\mathrm{N} / \mathrm{TCO}$ or $\mathrm{N} /$ metal contact at $x=L$, at the end of the semiconductor layers of the device, being at ground potential.

The input material and device parameters of the model are given in Table 1. The values chosen for a-Si:H are the best average values for the material developed in our laboratory. The parameters for pm-Si:H (e.g., hole mobility, initial and stabilised DOS, etc.) are those deduced from measured data in references $[1,5,8-10]$. The superior hole transport properties of pm-Si:H, as already pointed out in the introductory section, have been deduced from diffusion induced time resolved microwave conductivity [8] and time-of-flight measurements [9]. The DOS at the Fermi level $N\left(E_{F}\right)$ in the initial state has been measured on pm-Si:H samples using both capacitance measurements on Schottky barriers and space-charge-limited current (SCLC) measurements on $\mathrm{N}^{+} / \mathrm{I} / \mathrm{N}^{+}$structures [5]. From both techniques $N\left(E_{F}\right)$ values of $7-8 \times 10^{14} \mathrm{~cm}^{-3} \mathrm{eV}^{-1}$ have been obtained which is almost an order of magnitude lower than that measured [5] for a-Si:H $(\sim 5 \times$ $10^{15} \mathrm{~cm}^{-3} \mathrm{eV}^{-1}$ ) or reported in the literature for standard a-Si:H. In reference [1], the evolution of the sub-band gap absorption during accelerated light-soaking at $100{ }^{\circ} \mathrm{C}$ was studied for a-Si:H and pm-Si:H films. It was observed that the value of $\alpha(1.1 \mathrm{eV})$ at "saturation", namely $\alpha_{s s}$, is about an order of magnitude lower for pm-Si:H relative to a-Si:H. All the above results are representative of the study of a large number of samples grown under the same conditions. The Tauc's gap was determined from standard optical transmission measurements [1]. For both a-Si:H and pm-Si:H we have assumed the mobility gap to be $\sim 0.1 \mathrm{eV}$ larger than the corresponding optical gap.

\section{Results and discussion}

In performing the modelling we have relied heavily on the input parameters derived from simulating a-Si:H and pm-Si:H solar cells described in reference [11]. The reason for using the $\mathrm{P}-\mu \mathrm{c}-\mathrm{Si}: \mathrm{H} / \mathrm{P}-\mathrm{a}-\mathrm{SiC}: \mathrm{H}$ design is given in detail in reference [13] and for using the $\mathrm{P}-\mu \mathrm{c}-\mathrm{Si}: \mathrm{H} / \mathrm{P}-\mu \mathrm{c}-$ $\mathrm{SiO}_{x}: \mathrm{H}$ window structure described in the introductory section. However as already stated, we have also examined the $\mathrm{P}-\mu \mathrm{c}-\mathrm{SiO}_{x}: \mathrm{H}$ single window structure, assuming here a surface band bending of $0.2 \mathrm{eV}$, as for $\mathrm{P}-\mathrm{a}-\mathrm{SiC}: \mathrm{H}-\mathrm{a}$ value that is uncertain. The input parameters of the principal layers are given in Table 1 and their complex refractive indices shown in Figure 1. The $\mathrm{P} / \mathrm{I}$ interface dangling bond DOS is $2 \times 10^{16} \mathrm{~cm}^{-3}$ over $20 \mathrm{~nm}$ for the a-Si:H PIN cells, as inferred by modelling experimental results [11]. As the deposition of a pm-Si:H film involves a high flux of hydrogen to the substrate, we have preferred to study solar cells with this material deposited in a NIP configuration with the N-layer first on $\mathrm{ZnO}: \mathrm{Al} / \mathrm{Ag} /$ glass. The improvement in a pm-si:H solar cell output parameters when it is deposited in a NIP configuration has been demonstrated experimentally in reference [19]. This is because solar cell output is less sensitive to a damaged N/I interface than to a similarly damaged $\mathrm{I} / \mathrm{P}$ interface. This fact is demonstrated in Table 2 by modelling. In actual experiments, for pm-Si:H solar cells deposited in PIN and NIP configurations in our laboratory [19], it has been found that cells deposited in the latter configuration degrade much less from an initial efficiency of $\sim 9.3 \%$ to about $8.2 \%$; while those deposited in the PIN configuration degrade from a lower initial efficiency of $\sim 8.5 \%$ to $5.8 \%$, or even down to $3 \%$, in the worst cases after $500 \mathrm{~h}$ of light-soaking. The reason for this has been attributed to the creation of macroscopic defects such as blisters and delamination after light-soaking [19]. Coming back to modelling, the $\mathrm{N} / \mathrm{I}$ interface defect density for the pm-Si:H cells is taken $=5 \times 10^{17} \mathrm{~cm}^{-3}$ over the first $5 \mathrm{~nm}$, followed by an intermediate layer with a DOS of $2 \times 10^{16} \mathrm{~cm}^{-3}$ over $30 \mathrm{~nm}$, The existence of such an intermediate layer in pm-Si:H cells has been suggested by modelling in reference [11]. As already stated, in all cases an ultra-thin intrinsic buffer layer follows the window P-layers, both to prevent boron tailing into the main intrinsic layer and to achieve a lower interface defect density. As described in the introduction the back contact was either N-a-Si:H/ZnO:Al/Ag or N- $\mu$ c$\mathrm{SiO}_{x}: \mathrm{H} / \mathrm{Ag}$ with the $\mathrm{ZnO}: \mathrm{Al}$ left out in the case of a-Si:H solar cells deposited in the PIN configuration, but retaining a thin $\mathrm{ZnO}: \mathrm{Al}$ layer even for the latter design for the case of the pm-Si:H films, that are deposited in the NIP configuration. As mentioned earlier, this is to prevent silver diffusion into $\mathrm{N}-\mu \mathrm{c}-\mathrm{SiO}_{x}: \mathrm{H}$.

\subsection{The intrinsic layer}

The best solar cell output parameters of the a-Si:H solar cells deposited in our laboratory are given in the first 
Table 3. Solar cell output parameters of a-Si:H PIN cells with different window layers and back contacts in the initial and lightstabilised states. Light enters through the glass/ZnO:Al/P-layer. a-Si:H layer thickness is $200 \mathrm{~nm}$. ZnO in the table corresponds to aluminium-doped $\mathrm{ZnO}$. The first row gives our best experimental results [23] with a $20 \mathrm{~nm}$ pm-Si:H P/I buffer, while the rest are model calculations. The last line shows the effect of using $\mathrm{MgF}_{2} \mathrm{ARC}$ on glass.

\begin{tabular}{|c|c|c|c|c|c|}
\hline Cell structure & & $J_{\mathrm{sc}}\left(\mathrm{mA} \mathrm{cm}^{-2}\right)$ & $V_{\mathrm{oc}}($ volts $)$ & $\mathrm{FF}$ & Efficiency $(\%)$ \\
\hline Expt: Glass/ZnO/P- $\mu$ c-SiO $\mathrm{Si}_{x} /$ & Initial & 15.17 & 0.87 & 0.729 & 9.63 \\
\hline pm-Si:H/I-a-Si:H/N- $\mu$ c-Si:H/ZnO/Ag & Stabilised & 14.65 & 0.843 & 0.636 & 7.85 \\
\hline Glass/ZnO/P- $\mu \mathrm{c}-\mathrm{Si} / \mathrm{P}-\mathrm{a}-\mathrm{SiC} /$ & Initial & 15.55 & 0.988 & 0.782 & 12.01 \\
\hline I-a-Si:H/N-a-Si:H/ZnO/Ag & Stabilised & 15.01 & 0.933 & 0.603 & 8.83 \\
\hline Glass/ZnO/P- $\mu \mathrm{c}-\mathrm{Si} / \mathrm{P}-\mu \mathrm{c}-\mathrm{SiO}_{x}$ & Initial & 15.78 & 1.029 & 0.723 & 11.74 \\
\hline /I-a-Si:H/N-a-Si:H/ZnO/Ag & Stabilised & 15.37 & 0.943 & 0.611 & 8.86 \\
\hline Glass/ZnO/P- $\mu \mathrm{c}-\mathrm{Si} / \mathrm{P}-\mu \mathrm{c}-\mathrm{SiO}_{x} /$ & Initial & 16.07 & 1.032 & 0.729 & 12.09 \\
\hline I-a-Si:H/N- $\mu \mathrm{c}-\mathrm{SiO}_{x} / \mathrm{Ag}$ & Stabilised & 15.53 & 0.944 & 0.612 & 8.97 \\
\hline $\mathrm{MgF}_{2} /$ Glass/ZnO/P- $\mu \mathrm{c}-\mathrm{Si} /$ & Initial & 16.29 & 1.032 & 0.729 & 12.25 \\
\hline $\mathrm{P}-\mu \mathrm{c}-\mathrm{SiO}_{x} / \mathrm{I}-\mathrm{a}-\mathrm{Si}: \mathrm{H} / \mathrm{N}-\mu \mathrm{c}-\mathrm{SiO}_{x} / \mathrm{Ag}$ & Stabilised & 15.74 & 0.944 & 0.612 & 9.09 \\
\hline
\end{tabular}

Table 4. Solar cell output of pm-Si:H solar cells, deposited in the NIP configuration, but with the light entering on the P-side. The first row gives our best experimental results [19], while the rest are model calculations. In the second row, properties of pm-Si:H deposited at $175{ }^{\circ} \mathrm{C}$ are used, while in the rest those of pm-Si:H deposited at $210{ }^{\circ} \mathrm{C}$ are used. ZnO in the table corresponds to aluminium-doped $\mathrm{ZnO}$. The subsequent lines show the effect of different window layers and back contacts in the initial and light-stabilised states. The $\mathrm{ZnO}: \mathrm{Al} / \mathrm{P}-\mu \mathrm{c}-\mathrm{SiO}_{x}$ sbb is taken $=0.2 \mathrm{eV}$. The last two rows show the effect of using $\mathrm{MgF}_{2}$ $\mathrm{ARC}$ on $\mathrm{ZnO}: \mathrm{Al}$. Thickness of the pm-Si:H layer is $250 \mathrm{~nm}$ except for the last case where it is $150 \mathrm{~nm}$.

\begin{tabular}{|c|c|c|c|c|c|}
\hline Cell type & & $J_{\mathrm{sc}}\left(\mathrm{mA} \mathrm{cm}^{-2}\right)$ & $V_{\mathrm{oc}}($ volts $)$ & FF & Efficiency $(\%)$ \\
\hline Expt: ITO/P- $\mu \mathrm{c}-\mathrm{Si} / \mathrm{P}-\mu \mathrm{c}-\mathrm{SiO}_{x} /$ & Initial & 15.7 & 0.95 & 0.63 & 9.3 \\
\hline I-pm-Si:H/N-a-Si:H/SnO $2: F /$ glass & Stabilised & 15.0 & 0.93 & 0.60 & 8.2 \\
\hline $\mathrm{ZnO} / \mathrm{P}-\mu \mathrm{c}-\mathrm{Si} / \mathrm{P}-\mathrm{a}-\mathrm{SiC} / \mathrm{I}-\mathrm{pm}-\mathrm{Si}: \mathrm{H}$ & Initial & 13.31 & 0.985 & 0.792 & 10.39 \\
\hline$\left(175{ }^{\circ} \mathrm{C}\right) / \mathrm{N}-\mathrm{a}-\mathrm{Si}: \mathrm{H} / \mathrm{ZnO} / \mathrm{Ag} /$ glass & Stabilised & 13.22 & 0.980 & 0.744 & 9.63 \\
\hline $\mathrm{ZnO} / \mathrm{P}-\mu \mathrm{c}-\mathrm{Si} / \mathrm{P}-\mathrm{a}-\mathrm{SiC} / \mathrm{I}-\mathrm{pm}-\mathrm{Si}: \mathrm{H}$ & Initial & 14.48 & 0.987 & 0.792 & 11.32 \\
\hline$\left(210{ }^{\circ} \mathrm{C}\right) / \mathrm{N}-\mathrm{a}-\mathrm{Si}: \mathrm{H} / \mathrm{ZnO} / \mathrm{Ag} /$ glass & Stabilised & 14.38 & 0.982 & 0.743 & 10.5 \\
\hline $\mathrm{ZnO} / \mathrm{P}-\mu \mathrm{c}-\mathrm{Si} / \mathrm{P}-\mu \mathrm{c}-\mathrm{SiO}_{x} / \mathrm{I}-\mathrm{pm}-\mathrm{Si}: \mathrm{H} /$ & Initial & 15.02 & 1.106 & 0.748 & 12.43 \\
\hline $\mathrm{N}-\mathrm{a}-\mathrm{Si}: \mathrm{H} / \mathrm{ZnO} / \mathrm{Ag} /$ glass & Stabilised & 14.89 & 1.061 & 0.694 & 10.97 \\
\hline $\mathrm{ZnO} / \mathrm{P}-\mu \mathrm{c}-\mathrm{Si} / \mathrm{P}-\mu \mathrm{c}-\mathrm{SiO}{ }_{x} / \mathrm{I}-\mathrm{pm}-\mathrm{Si}: \mathrm{H} /$ & Initial & 15.29 & 1.140 & 0.772 & 13.45 \\
\hline $\mathrm{N}-\mu \mathrm{c}-\mathrm{SiO}_{x} / \mathrm{ZnO} / \mathrm{Ag} /$ glass & Stabilised & 15.15 & 1.073 & 0.701 & 11.40 \\
\hline $\mathrm{ZnO} / \mathrm{P}-\mu \mathrm{c}-\mathrm{SiO}_{x} / \mathrm{I}-\mathrm{pm}-\mathrm{Si}: \mathrm{H} /$ & Initial & 15.89 & 1.124 & 0.760 & 13.56 \\
\hline $\mathrm{N}-\mu \mathrm{c}-\mathrm{SiO}_{x} / \mathrm{ZnO} / \mathrm{Ag} /$ glass & Stabilised & 15.74 & 1.057 & 0.687 & 11.43 \\
\hline $\mathrm{MgF}_{2} / \mathrm{ZnO} / \mathrm{P}-\mu \mathrm{c}-\mathrm{SiO}_{x} / \mathrm{I}-\mathrm{pm}-\mathrm{Si}: \mathrm{H} /$ & Initial & 16.64 & 1.125 & 0,759 & 14.20 \\
\hline $\mathrm{N}-\mu \mathrm{c}-\mathrm{SiO}_{x} / \mathrm{ZnO} / \mathrm{Ag} /$ glass & Stabilised & 16.49 & 1.059 & 0.686 & 11.98 \\
\hline $\mathrm{MgF}_{2} / \mathrm{ZnO} / \mathrm{P}-\mu \mathrm{c}-\mathrm{SiO}_{x} /$ & Initial & 15.98 & 1.129 & 0.764 & 13.78 \\
\hline I-pm-Si:H/N- $\mu$ c-SiO ${ }_{x} / \mathrm{ZnO} / \mathrm{Ag} /$ glass & Stabilised & 15.92 & 1.080 & 0.714 & 12.27 \\
\hline
\end{tabular}

row of Table 3 and those of the best pm-Si:H solar cells in the first row of Table 4 . The remaining rows of the two tables give modelling results with improvements in the output parameters likely to occur when various emitter designs and N-layers are used. For both types of material, we studied the effect of the substrate temperature to see whether any improvement in the absorption coefficient, linked to the extinction coefficients $(\kappa)$ could be achieved. No such increase was observed for a-Si:H over a range of temperatures around $200{ }^{\circ} \mathrm{C}$, but the $\kappa$ 's of pm-Si:H increased somewhat when the deposition temperature was increased from $175{ }^{\circ} \mathrm{C}$ to $210{ }^{\circ} \mathrm{C}$ (Fig. 1a), resulting in superior values of $J_{\mathrm{sc}}$ (compare the results of the second and third rows of Tab. 4) and the EQE given in Figure 4a.

Comparing Tables 3 and 4 for the a-Si:H and pmSi:H PIN cells respectively, we note that although in most cases, the initial $J_{\mathrm{sc}}$ in a-Si:H cells is higher, the stabilised efficiency is lower than in pm-Si:H cells. The reason for higher current is the stronger absorption (higher coefficient of extinction - Fig. 1a) of long wavelength visible light in a-Si:H relative to pm-Si:H. On the other hand the stabilised dangling bond density in a-Si:H is one order of magnitude higher than in pm-Si:H (see Tab. 1) and this fact in conjunction with a lower hole mobility than in pm$\mathrm{Si}: \mathrm{H}$ brings down sharply the stabilised efficiency in a-Si:H PIN cells. In fact, we have been able to achieve $12 \%$ stabilised efficiency in pm-Si:H solar cells (Tab. 4), but not as yet in a-Si:H cells (Tab. 3) using parameters extracted by simulating our experimental results.

\subsection{The window and emitter design}

Figures $3 \mathrm{a}$ and $3 \mathrm{~b}$ depict respectively typical band diagrams of a-Si:H and pm-Si:H PIN cells having a two-window $\mathrm{P}-\mu \mathrm{c}-\mathrm{Si}: \mathrm{H} / \mathrm{P}-\mu \mathrm{c}-\mathrm{SiO}_{x}: \mathrm{H}$ structure and a 
Table 5. Sensitivity of the pm-Si:H solar cell output to the band edge line-up between $\mathrm{P}-\mu \mathrm{c}-\mathrm{SiO} x: \mathrm{H}$ and pm-Si:H in cells employing a single window layer in the initial state. $\Delta E_{c}$ and $\Delta E_{v}$ are respectively the conduction band and valence band discontinuities and $\Delta E_{\mu}$ the band gap discontinuity between the two. In Table 4 throughout we had assumed $\Delta E_{c}=\Delta E_{v}=$ $\Delta E_{\mu} / 2$.

\begin{tabular}{|c|c|c|c|c|c|}
\hline $\begin{array}{c}\text { ZnO:Al/P- } \mu \text { c-SiO }{ }_{x} / \mathrm{I}-\mathrm{pm}-\mathrm{Si}: \mathrm{H} / \\
\mathrm{N}-\mu \mathrm{c}-\mathrm{SiO}_{x} / \mathrm{ZnO}: \mathrm{Al} / \mathrm{Ag} / \text { glass }\end{array}$ & $\begin{array}{c}V_{\mathrm{bi}} \\
(\text { volts })\end{array}$ & $\begin{array}{c}J_{\mathrm{sc}} \\
\left(\mathrm{mA} \mathrm{cm}^{-2}\right)\end{array}$ & $\begin{array}{c}V_{\mathrm{oc}} \\
\text { (volts) }\end{array}$ & $\overline{\mathrm{FF}}$ & $\begin{array}{l}\text { Efficiency } \\
(\%)\end{array}$ \\
\hline $\begin{array}{c}\mathrm{P}-\mu \mathrm{c}-\mathrm{SiO}_{x} / \mathrm{pm}-\mathrm{Si} \\
\Delta E_{\mathrm{c}}=\Delta E_{v}=\Delta E_{\mu} / 2\end{array}$ & 1.566 & 15.89 & 1.124 & 0.760 & 13.56 \\
\hline $\begin{array}{c}\mathrm{P}-\mu \mathrm{c}-\mathrm{SiO}_{x} / \mathrm{pm}-\mathrm{Si} \\
\Delta E_{c}=0, \Delta E_{v}=\Delta E_{\mu}=0.54 \mathrm{eV}\end{array}$ & 1.814 & 16.26 & 1.162 & 0.198 & 3.74 \\
\hline $\begin{aligned} & \mathrm{P}-\mu \mathrm{c}-\mathrm{SiO}_{x} / \mathrm{pm}-\mathrm{Si} \\
\Delta E_{v}= & 0, \Delta E_{c}=\Delta E_{\mu}=0.54 \mathrm{eV}\end{aligned}$ & 1.314 & 15.82 & 1.143 & 0.736 & 13.31 \\
\hline
\end{tabular}
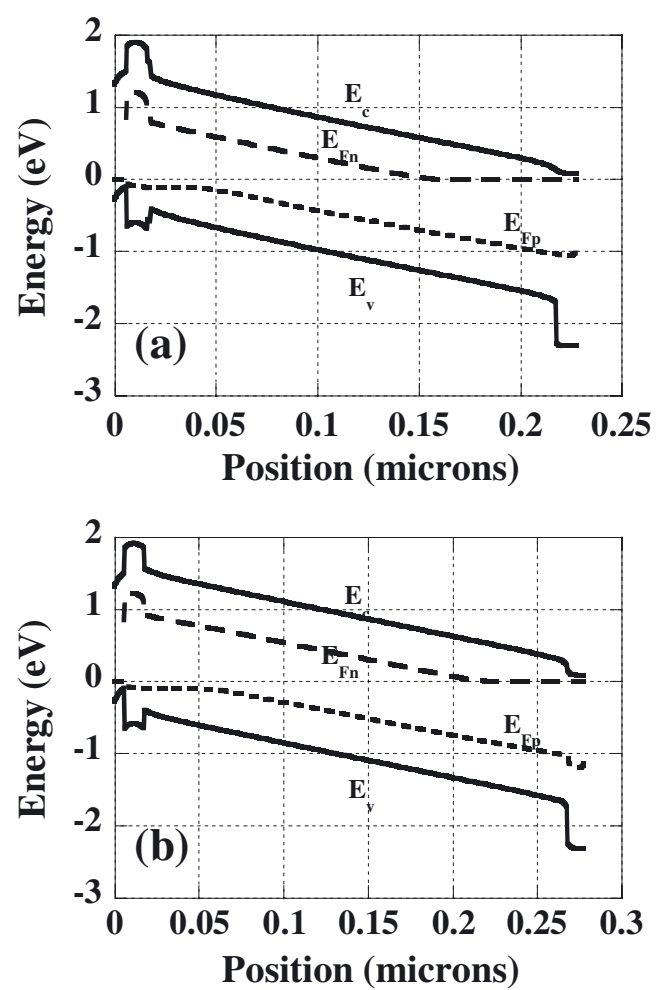

Fig. 3. Typical band diagrams under AM 1.5 light and shortcircuit conditions in the annealed state of (i) a a-Si:H single junction solar cell having a $\mathrm{P}-\mu \mathrm{c}-\mathrm{Si}: \mathrm{H} / \mathrm{P}-\mu \mathrm{c}-\mathrm{SiO}_{x}: \mathrm{H}$ double window design and a $\mu \mathrm{c}-\mathrm{SiO}_{x} \mathrm{~N}$-layer; and (ii) a pm-Si:H solar cell with identical emitter and N-layer designs under the same conditions.

$\mu \mathrm{c}-\mathrm{SiO}_{x}: \mathrm{H}$ N-layer, under AM1.5 light illumination and short-circuit conditions, in the initial state. On the other hand, Figure 4b shows the EQE curves of a pm-Si:H single junction cell with the following doped layers: (i) P- $\mu$ c-Si:H/P-a-SiC:H emitter layer and a-Si:H N-layer, (ii) $\mathrm{P}-\mu \mathrm{c}-\mathrm{Si}: \mathrm{H} / \mathrm{P}-\mu \mathrm{c}-\mathrm{SiO}_{x}: \mathrm{H}$ and N-a-Si:H, (iii) $\mathrm{P}-\mu \mathrm{c}-\mathrm{Si}: \mathrm{H} / \mathrm{P}-$ $\mu \mathrm{c}-\mathrm{SiO}_{x}: \mathrm{H}$ and and $\mathrm{N}-\mu-\mathrm{SiO}_{x}: \mathrm{H}$ and (iv) a single $\mathrm{P}-\mu \mathrm{c}-$ $\mathrm{SiO}_{x}: \mathrm{H}$ emitter with $\mathrm{N}-\mu-\mathrm{SiO}_{x}: \mathrm{H}$. Additionally, Figure $4 \mathrm{c}$ shows the effect of a $\mathrm{MgF}_{2}$ anti-reflection coating (ARC) on the last case, while Figure $4 \mathrm{~d}$ depicts the stabilised state EQE of Figure 4c. In Figure 5 we draw the EQE curves corresponding to the a-Si:H cells described in the second, third and fourth rows of Table 3 in the initial
(Fig. 5a) and the light-stabilised (Fig. 5b) states. $\mathrm{A} \mathrm{MgF}_{2}$ ARC on glass produces negligible improvement as seen by comparing the last two rows of Table 3 ; hence this case is not included in Figure 5.

In the results given in Tables 3 and 4 , the $\mathrm{P}$-a-SiC:H and I-a-Si:H or I-pm-Si:H band discontinuity is apportioned to the conduction band side, as inferred from reference [16]. Since there is no valence band discontinuity, the $\mathrm{FF}$ is better in this case than when $\mathrm{P}-\mu \mathrm{c}-\mathrm{SiO}_{x}: \mathrm{H}$ is used. In the latter case, in the absence of any measured data (to our knowledge), we have apportioned half the band discontinuity to the valence band and this fact hinders hole collection and brings down the FF. Also the sbb is $0.16 \mathrm{eV}$ for TCO/P- $\mu \mathrm{c}-\mathrm{Si}: \mathrm{H}[14]$. As there are no experimental data for the TCO/P- $\mu \mathrm{c}-\mathrm{SiO}_{x}: \mathrm{H}$ band bending, we have taken the value of $0.2 \mathrm{eV}$ (sixth row of Tab. 4), that is generally encountered at the TCO/P-a-SiC:H contact. The consequences on the solar cell output of changing the band edge line up and $\mathrm{TCO} / \mathrm{P}-\mu \mathrm{c}-\mathrm{SiO}_{x}: \mathrm{H}$ sbb are shown in Tables 5 and 6 , respectively. Note that the effects of changing the band edge line-up and the sbb for the single $\mathrm{P}-\mu \mathrm{c}-\mathrm{SiO}_{x}: \mathrm{H}$ design are shown only for the pm-Si:H PIN cell, since the variation is similar in a-Si:H cells, and, such a cell is more promising than an a-Si:H one, from the point of view of the stabilised efficiency. From Table 5, apportioning the entire band gap discontinuity to the valence band side leads to a higher built-in field and $V_{\mathrm{oc}}$, but a strongly reduced $\mathrm{FF}$, as the high $\Delta E_{v}$ hinders hole collection. However, in spite of $\Delta E_{c}$ being taken equal to zero for this case (a fact that may be expected to encourage electron back diffusion leading to a lower current), the current actually increases, indicating that the high $V_{b i}$, and consequently the higher field in this device, more than cancels the detrimental effect of $\Delta E_{c}=0$ on $J_{\mathrm{sc}}$. When the entire band gap discontinuity is on the conduction band side (row 3 of Tab. 5), no improvement in $J_{\mathrm{sc}}$ is seen over row 1 of the same table, indicating that even $\Delta E_{c}=\Delta E_{\mu} / 2$ is sufficient to block the back diffusion of electrons. $V_{\mathrm{bi}}$ decreases for this case as expected, leading to a fall in the FF relative to row 1; surprisingly however $V_{\text {oc }}$ increases. This fact may be explained as follows: as $\Delta E_{v}=0$, and as we have assumed low I/P (P-layer deposited on top of I layer) interface defect density (our pm-Si:H cell has been deposited in a NIP configuration, so that the I/P interface is not damaged), negligible hole accumulation at this 

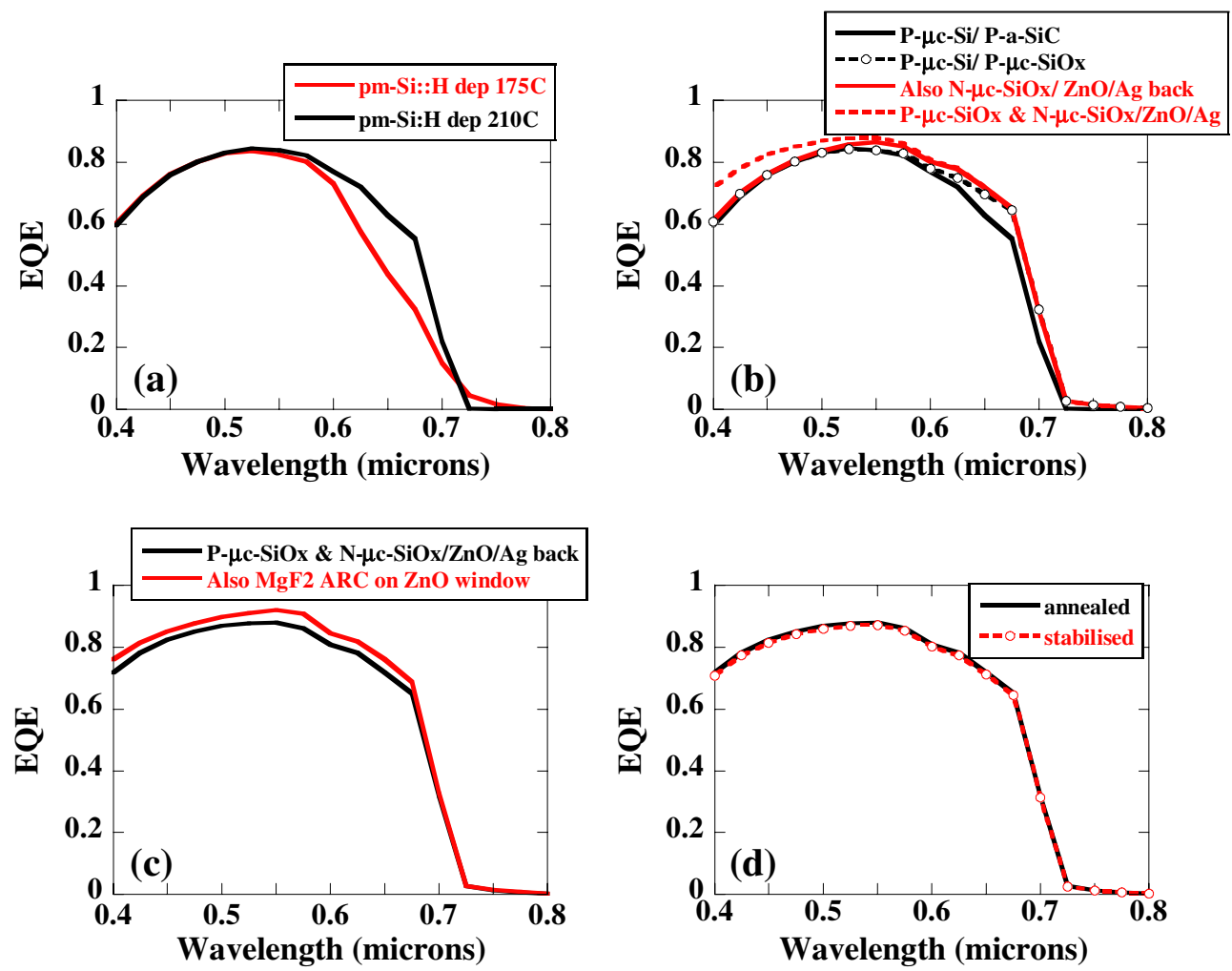

Fig. 4. Comparison of the external quantum efficiency (EQE) of pm-Si:H solar cells having (a) $\mathrm{P}-\mu \mathrm{c}-\mathrm{Si}: \mathrm{H} / \mathrm{P}-\mathrm{a}-\mathrm{SiC}: \mathrm{H}$ double window design with an a-Si:H N-layer, but pm-Si:H intrinsic layers deposited at $175{ }^{\circ} \mathrm{C}$ and $210{ }^{\circ} \mathrm{C}$ in the initial state; (b) 4 types of solar cells in the initial state with $\mathrm{P}-\mu \mathrm{c}-\mathrm{Si}: \mathrm{H} / \mathrm{P}-\mathrm{a}-\mathrm{SiC}: \mathrm{H}$ and $\mathrm{P}-\mu \mathrm{c}-\mathrm{Si}: \mathrm{H} / \mathrm{P}-\mu \mathrm{c}-\mathrm{SiO}_{x}$ double window designs both with a-Si:H N-layers, the latter emitter design with $\mathrm{N}-\mathrm{a}-\mathrm{Si}: \mathrm{H}$ replaced by $\mathrm{N}-\mu \mathrm{c}-\mathrm{SiO}_{x}$ and the last design: with a single $\mathrm{P}-\mu \mathrm{c}-\mathrm{SiO}{ }_{x}: \mathrm{H}$ emitter; (c) the latter design in the initial state with and without a $\mathrm{MgF}_{2}$ anti-reflection coating on the $\mathrm{ZnO}$ :Al window and (d) the $\mathrm{ZnO}: \mathrm{Al} / \mathrm{P}-\mu \mathrm{c}-\mathrm{SiO}_{x} / \mathrm{I}-\mathrm{pm}-\mathrm{Si}: \mathrm{H} / \mathrm{N}-\mu \mathrm{c}-\mathrm{SiO}_{x} / \mathrm{ZnO}: \mathrm{Al} / \mathrm{Ag} /$ glass cell in the initial and light-stabilised states.

Table 6. Sensitivity of the pm-Si:H solar cell output to the $\mathrm{ZnO}: \mathrm{Al} / \mathrm{P}-\mu \mathrm{c}-\mathrm{SiO}_{x}: \mathrm{H}$ surface band bending. The case where the $\mathrm{sbb}=0.2 \mathrm{eV}$ (that is generally observed for $\mathrm{ZnO}: \mathrm{Al} / \mathrm{P}-\mathrm{a}-\mathrm{SiC}: \mathrm{H}$ ), is given in the first row of this table and assumed for the single window designs in Table 4 . The front contact barrier height $\left(\varphi_{\mathrm{b} 0}\right)$ for this case is $1.83 \mathrm{eV}$, since the band gap of $\mathrm{P}-\mu \mathrm{c}-\mathrm{SiO} \mathrm{O}_{x}$ is taken to be $2.5 \mathrm{eV}$ and its activation energy $=0.47 \mathrm{eV}$. Even for a slight increase of sbb - to $0.3 \mathrm{eV}\left(\varphi_{b 0}=1.73 \mathrm{eV}\right), V_{\mathrm{oc}}, \mathrm{FF}$ and the cell efficiency deteriorate appreciably (second line of table), as the $V_{\mathrm{bi}}$ falls. Any effort to increase the $V_{\mathrm{bi}}$ by increasing the $\mathrm{P}-\mu \mathrm{c}-\mathrm{SiO}_{x}: \mathrm{H}$ thickness, brings down the $J_{\mathrm{sc}}$. The third line indicates the effect of having $\varphi_{b 0}=1.32 \mathrm{eV}$, the same as at the $\mathrm{ZnO}: \mathrm{Al} / \mathrm{P}-\mu \mathrm{c}-\mathrm{Si}: \mathrm{H}$ interface of the double window design.

\begin{tabular}{cccccc}
\hline Cell type & & $J_{\mathrm{sc}}\left(\mathrm{mA} \mathrm{cm}^{-2}\right)$ & $V_{\text {oc }}($ volts $)$ & FF & Efficiency $(\%)$ \\
\hline $\begin{array}{c}\text { pm-Si:H, } \mathrm{ZnO}: \mathrm{Al} / \mathrm{P}-\mu \mathrm{c}-\mathrm{SiO}_{x}: \mathrm{H} \\
\mathrm{sbb}=0.2 \mathrm{eV}, \varphi_{b 0}=1.83 \mathrm{eV}\end{array}$ & Initial & 15.89 & 1.124 & 0.760 & 13.56 \\
\hline $\begin{array}{c}\mathrm{pm}-\mathrm{Si}: \mathrm{H}, \mathrm{ZnO}: \mathrm{Al} / \mathrm{P}-\mu \mathrm{c}-\mathrm{SiO}_{x}: \mathrm{H} \\
\mathrm{sbb}=0.3 \mathrm{eV}, \varphi_{b 0}=1.73 \mathrm{eV}\end{array}$ & Initial & 15.88 & 1.039 & 0.732 & 12.07 \\
\hline $\begin{array}{c}\mathrm{pm}-\mathrm{Si}: \mathrm{H}, \mathrm{ZnO}: \mathrm{Al} / \mathrm{P}-\mu \mathrm{c}-\mathrm{SiO}_{x}: \mathrm{H} \\
\mathrm{sbb}=0.71 \mathrm{eV} \varphi_{\mathrm{b} 0}=1.32 \mathrm{eV}\end{array}$ & Initial & 15.81 & 0.629 & 0.614 & 6.11 \\
\hline
\end{tabular}

interface takes place for this case, leading to low interface field and more field in the bulk of the device that brings up $V_{\text {oc }}$.

Now comparing the results of Veneri et al. [17] to the solar cell output parameters of the a-Si:H cells given in Table 3 , we note that our $V_{\text {oc }}$ 's are considerably higher. Modelling also yields a higher $V_{\mathrm{oc}}$ than that achieved experimentally $[19,23]$. In such a heterojunction structure, where the $\mathrm{P}-\mu \mathrm{c}-\mathrm{SiO}_{x}$ band gap is considerably higher than that of I-a-Si:H or I-pm-Si:H (Tab. 1), the band edge line up has a strong influence on the FF (as seen from the modelling results in Tab. 5 for the case of a pm-Si:H cell, the effect on an a-Si:H cell is similar). Therefore, taking a comparison with the FF values given in reference [17], 19 and 23 , no more than half the band gap discontinuity can lie on the valence band side, as assumed by us for all cases in Table 3 . However the fact that our calculated $V_{\mathrm{oc}}$ is higher than the measured results $[17,19,23]$, independently of this band edge line up (as shown in the example of pm-Si:H cells in Tab. 5), indicates that in the experimental cases, 
Table 7. Optimisation of the thickness of the pm-Si:H absorber layer for a double P-layer window design: $\mathrm{P}-\mu \mathrm{c}-\mathrm{Si}: \mathrm{H} / \mathrm{P}-\mu \mathrm{c}-$ $\mathrm{SiO}_{x}: \mathrm{H}$ and $\mathrm{N}-\mu \mathrm{c}-\mathrm{SiO}_{x} / \mathrm{ZnO}: \mathrm{Al} / \mathrm{Ag}$ back structure. Results indicate that any thickness between $250 \mathrm{~nm}$ and $150 \mathrm{~nm}$ is good with the thinnest pm-Si:H cell having an edge regarding the stabilised efficiency.

\begin{tabular}{cccccc}
\hline $\begin{array}{l}\mathrm{ZnO}: \mathrm{Al} / \mathrm{P}-\mu \mathrm{c}-\mathrm{Si} / \mathrm{P}-\mu \mathrm{c}-\mathrm{SiO} \\
\mathrm{Si} / \mathrm{I} / \mathrm{I}-\mathrm{pm}-\mu \mathrm{c}-\mathrm{SiO}_{x} / \mathrm{ZnO}: \mathrm{Al} / \mathrm{Ag} / \text { glass }\end{array}$ & & $J_{\mathrm{sc}}\left(\mathrm{mA} \mathrm{cm}^{-2}\right)$ & $V_{\text {oc }}($ volts $)$ & FF & Efficiency $(\%)$ \\
\hline Thickness $=250 \mathrm{~nm}$ & Initial & 15.29 & 1.140 & 0.772 & 13.45 \\
& Stabilised & 15.15 & 1.073 & 0.701 & 11.40 \\
\hline Thickness $=300 \mathrm{~nm}$ & Initial & 15.48 & 1.138 & 0.767 & 13.51 \\
& Stabilised & 15.29 & 1.065 & 0.685 & 11.16 \\
\hline Thickness $=200 \mathrm{~nm}$ & Initial & 14.99 & 1.143 & 0.775 & 13.29 \\
& Stabilised & 14.90 & 1.082 & 0.715 & 11.53 \\
\hline Thickness $=150 \mathrm{~nm}$ & Initial & 14.61 & 1.145 & 0.781 & 13.07 \\
& Stabilised & 14.56 & 1.094 & 0.731 & 11.64 \\
\hline
\end{tabular}
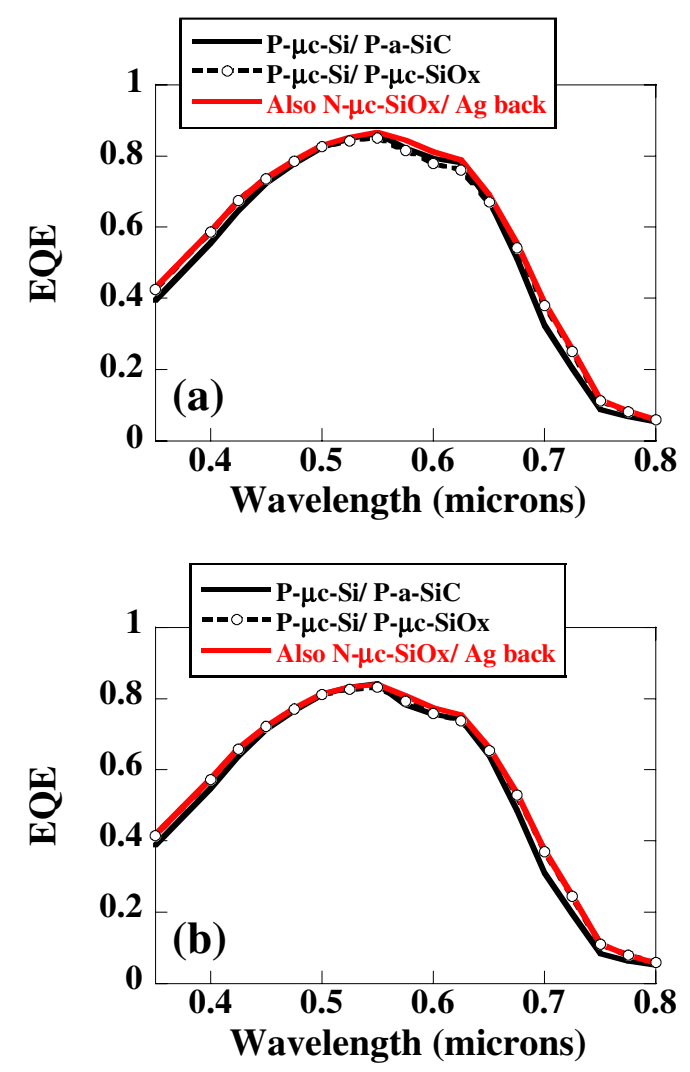

Fig. 5. Comparison of the EQE curves of a-Si:H solar cells in the (a) initial and (b) light stabilised states having different window designs and N-layer: with $\mathrm{P}-\mu \mathrm{c}-\mathrm{Si}: \mathrm{H} / \mathrm{P}-\mathrm{a}-\mathrm{SiC}: \mathrm{H}$ and $\mathrm{P}-\mu \mathrm{c}-\mathrm{Si}: \mathrm{H} / \mathrm{P}-\mu \mathrm{c}-\mathrm{SiO}_{x}: \mathrm{H}$ double window designs both with a$\mathrm{Si}: \mathrm{H}$ N-layers and the latter emitter design with N-a-Si:H replaced by $\mathrm{N}-\mu \mathrm{c}-\mathrm{SiO}_{x}$.

the $\mathrm{P} / \mathrm{I}$ interface is more defective than assumed in our calculations, and points to the fact that the $V_{\mathrm{oc}}$ and the cell efficiency may be considerably improved by improving the quality of the $\mathrm{P} / \mathrm{I}$ interface.

We find from Tables 3 and 4 and Figures $4 \mathrm{~b}$ and 5 , that in both a-Si:H and pm-Si:H cells there is an increase in the current density when the $\mathrm{P}-\mathrm{a}-\mathrm{SiC}: \mathrm{H}$ layer is substituted by $\mathrm{P}-\mu \mathrm{c}-\mathrm{SiO}_{x}: \mathrm{H}$. This fact is due to the lower absorption coefficients of $\mathrm{P}-\mu \mathrm{c}-\mathrm{SiO}_{x}$ that is linked to the imaginary part of the CRIND's input to the program - Figure 1c (the real part of the CRIND's of the different P-layers studied are plotted as a function of wavelength in Fig. 1d). The EQE curves indicate that it is mainly the increase in the long wave length response that contributes to the current increase. The absence of an appreciable increase in the short wavelength EQE is due to the fact that $\mathrm{P}-\mu \mathrm{c}-\mathrm{SiO}_{x}$, being micro-crystalline, has been assumed thicker than the amorphous $\mathrm{P}-\mathrm{a}-\mathrm{SiC}: \mathrm{H}$ layer, so that a possible increase in the blue response due to lower absorption coefficients of the former is annulled. Our EQE curves in Figure 5a for a $\mathrm{PIN}$ a-Si:H cell both having a $\mathrm{P}-\mu \mathrm{c}-\mathrm{SiO}_{x}$ window layer but with the back contact design $\mathrm{N}-\mathrm{a}-\mathrm{Si}: \mathrm{H} / \mathrm{ZnO}: \mathrm{Al} / \mathrm{Ag}$ in one case (black dotted line) and $\mathrm{N}-\mu \mathrm{c}-\mathrm{SiO}_{x} / \mathrm{Ag}$ in the other (red line) agree quite well with the EQE curves of Veneri et al. [17] $\left(R=0 \mathrm{~N}-\mu \mathrm{c}-\mathrm{Si} / \mathrm{ZnO} / \mathrm{Ag}\right.$ and $\mathrm{N}-\mu \mathrm{c}-\mathrm{SiO}_{x} / \mathrm{Ag}$ back contacts) except for wavelengths in the range of $0.65 \mu \mathrm{m} \leqslant \lambda \leqslant 0.7 \mu \mathrm{m}$, where our EQE curves are lower in both cases. This may be due to lower values of the imaginary part of the CRIND's for those wavelengths for the a-Si:H material developed in our laboratory.

Also from Table 4 and Figure $4 \mathrm{~b}$, we note that for the single window design with $\mathrm{P}-\mu \mathrm{c}-\mathrm{SiO}_{x}: \mathrm{H}$, the current is appreciably higher, since $\mathrm{P}-\mu \mathrm{c}-\mathrm{Si}: \mathrm{H}$ is absent, but $V_{\text {oc }}$ and $\mathrm{FF}$ are lower (because now we cannot take advantage of the lower $E_{\mathrm{ac}}$ and sbb of $\left.\mathrm{P}-\mu \mathrm{c}-\mathrm{Si}: \mathrm{H}\right)$ yielding nearly the same initial and stabilised efficiency. However in the case of the single $\mathrm{P}-\mu \mathrm{c}-\mathrm{SiO}_{x}: \mathrm{H}$ window layer the uncertainty of the value of the $\mathrm{TCO} / \mathrm{P}-\mu \mathrm{c}-\mathrm{SiO}_{x}: \mathrm{H}$ sbb may be a crucial limiting factor as is evident from Table 6 . Due to the large sensitivity to the $\mathrm{TCO} / \mathrm{P}-\mu \mathrm{c}-\mathrm{SiO}_{x}: \mathrm{H}$ sbb about which little is known at the moment and because, as seen from Table 4, there is negligible difference between the initial and stabilised efficiencies for the double window structure - $\mathrm{ZnO}: \mathrm{Al} / \mathrm{P}-\mu \mathrm{c}-\mathrm{Si}: \mathrm{H} / \mathrm{P}-\mu \mathrm{c}-\mathrm{SiO}_{x}: \mathrm{H}$, and the single window structure $-\mathrm{ZnO}: \mathrm{Al} / \mathrm{P}-\mu \mathrm{c}-\mathrm{SiO}_{x}: \mathrm{H}$ (when this sbb is taken $=0.2 \mathrm{eV}$ ), it was decided to choose the former design to optimise the thickness of the pm-Si:H film grown at $210{ }^{\circ} \mathrm{C}$. This is because for this case we have a fairly good idea the $\mathrm{ZnO}: \mathrm{Al} / \mathrm{P}-\mu \mathrm{c}-\mathrm{Si}: \mathrm{H}$ sbb [14]. The results of thickness optimisation are given in Table 7 and show that any thickness between $250 \mathrm{~nm}$ and $150 \mathrm{~nm}$ is acceptable, with the thinnest pm-Si:H cell having a small advantage regarding the stabilised efficiency. 
Finally a $\mathrm{MgF}_{2}$ ARC deposited on $\mathrm{ZnO} \mathrm{Al}$, through which light enters the pmSi:H cell with the NIP configuration on glass (Fig. 2b), strongly enhances $J_{\mathrm{sc}}$ (Tab. 4) and the EQE (Fig. 4c). However, only a small improvement is observed in the case of the a-Si:H cell in the PIN configuration with $\mathrm{MgF}_{2}$ deposited on glass (Tab. 3).

\subsection{The $\mathrm{N}$-side design}

Tables 3 and 4 and the EQE curves of Figures $4 \mathrm{~b}$ and 5 show the effect of substituting $\mathrm{N}-\mu \mathrm{c}-\mathrm{SiO}_{x}: \mathrm{H}$ in place of N-a-Si:H. This brings up $J_{\mathrm{sc}}$ and the long wavelength EQE. For this layer the electrical and optical parameters have been taken from reference [17] in our simulation. This material with the real part $n$, of the complex refractive index considerably lower than that of N-a-Si:H and close to that of $\mathrm{ZnO}: \mathrm{Al}$ (Fig. 1f), appreciably improves the long wavelength EQE. Indeed most of the light is now reflected at the I-layer $/ \mathrm{N}-\mu \mathrm{c}-\mathrm{SiO}_{x}$ interface and therefore does not need to cross the N-layer twice. Also it is nearly as transparent as $\mathrm{ZnO}: \mathrm{Al}$, with values of the extinction coefficient close to those of the latter (Fig. 1e). Since as well, its doping can be adjusted to make it highly conducting $\left(E_{\mathrm{ac}}=0.09 \mathrm{eV}\right.$, lower than that of N-a-Si:H Tab. 1), it can effectively act both as the TCO and the N-layer of the structure [17]; also leading to improvements in $V_{\text {oc }}$ and FF. Moreover, the deposition of an extra TCO layer may be avoided in this case. However the pm-Si:H cell has to be deposited in a NIP configuration, to avoid a very damaged $\mathrm{I} / \mathrm{P}$ interface and macroscopic defects as already stated. Here a thin layer of $\mathrm{ZnO}$ :Al needs to be deposited on silver, to prevent the latter diffusing into the $\mathrm{N}$-layer when the $\mathrm{N}$-side of the junction is bombarded by a high flux of hydrogen required to form pm-Si:H. Thus in pm-Si:H cells, although the deposition of an extra TCO layer cannot be avoided, the use of $\mathrm{N}-\mu \mathrm{c}-\mathrm{SiO}_{x}: \mathrm{H}$ instead of $\mathrm{N}-\mathrm{a}-\mathrm{Si}: \mathrm{H}$ is still advantageous as can be seen from the 5 th row of Table 4, and Figure 4b.

\section{Conclusions}

The possibility of single junction pm-Si:H solar cells with stabilised efficiencies around $12 \%$ has been demonstrated by modelling. We have shown that in order to achieve such efficiencies the pm-Si:H cell should be deposited in the NIP rather than the PIN configuration to avoid a heavily damaged $\mathrm{P} / \mathrm{I}$ interface that is much more harmful for the solar cell efficiency than a similarly damaged N/I interface; and to avoid formation of macroscopic defects on the P-layer side. However light should enter the cell through the P-layer. A $\mathrm{P}-\mu \mathrm{c}-\mathrm{SiO}_{x}: \mathrm{H}$ window layer, a suitably $\mathrm{N}$-doped $\mu \mathrm{c}-\mathrm{SiO}_{x}: \mathrm{H}$, as well as a $\mathrm{MgF}_{2} \mathrm{ARC}$ on $\mathrm{ZnO}: \mathrm{Al}$ are required to achieve this goal. On the contrary, using the initial and stabilised state properties and interface parameters of the best a-Si:H material and solar cell developed in our laboratory so far, we could not achieve $10 \%$ stabilised efficiency in a-Si:H PIN solar cells, as the stabilised DOS in this material is high and its hole mobility considerably lower than in pm-Si. However such a landmark has been achieved in a few other laboratories e.g. reference [18], probably due to better light absorption in their material, improved $\mathrm{P} / \mathrm{I}$ interface properties in solar cells fabricated with this material, etc.

The calculated solar cells have a lower FF but a higher $V_{\text {oc }}$ when $\mathrm{P}-\mu \mathrm{c}-\mathrm{SiO}_{x}: \mathrm{H}$ forms part of the window layer than for the P-a-SiC:H case. The higher $V_{\text {oc }}$ is due to a higher built-in field in the former case, while the lower FF for $\mathrm{P}-\mu \mathrm{c}-\mathrm{SiO}_{x}$ is due to an assumed $\Delta E_{v}=0.26 \mathrm{eV}$, that hinders hole collection, while $\Delta E_{v}$ is $\sim 0$ for P-a-SiC:H. The solar cells using $\mathrm{P}-\mu \mathrm{c}-\mathrm{SiO}_{x}: \mathrm{H}$ show higher current density, due to the lower coefficient of extinction of this material compared to P-a-SiC:H. Also modelling shows that highly conducting and transparent $\mathrm{N}-\mu \mathrm{c}-\mathrm{SiO}_{x}: \mathrm{H}$ can act both as the N-layer of the structure and the TCO. In fact this material with a refractive index considerably lower than that of $\mathrm{N}-\mathrm{a}-\mathrm{Si}: \mathrm{H}$ and close to that of $\mathrm{ZnO}: \mathrm{Al}$, appreciably improves the long wavelength $\mathrm{QE}$, since most of the light is now reflected at the I-layer $/ \mathrm{N}-\mu \mathrm{c}-\mathrm{SiO}_{x}$ interface and does not need to cross the N-layer twice. The improvements in the solar cell output parameters due to the use of the P- and N-layers described above and as deduced from modelling will be applicable independent of the absorber material used in the PIN solar cell.

In our calculations, there is uncertainty in the calculated solar cell output, due to the limited knowledge on the band edge line up of $\mathrm{P}-\mu \mathrm{c}-\mathrm{SiO}_{x}$ with I-a-Si:H or I-pm$\mathrm{Si}: \mathrm{H}$, and its surface band bending at the contact with $\mathrm{ZnO}: \mathrm{Al}$ when used in the single window design. The effect of varying these parameters has been demonstrated. The latter uncertainty may be avoided by using the double window design. Also we have shown that $\Delta E_{v}$ cannot be higher than half the band gap discontinuity in order to attain the high experimental values of FF $[17,19,23]$. Moreover we infer that the $V_{\text {oc }}$ in the deposited solar cells may be considerably increased by lowering the $\mathrm{P} / \mathrm{I}$ interface defect density. We conclude, as Table 4 indicates, that $\sim 12 \%$ stabilised efficiency is achievable in thin pm$\mathrm{Si}: \mathrm{H}$ single junction solar cells (thickness of the I-layer $\leqslant 250 \mathrm{~nm}$ ) with practical material and device parameters and a suitable anti-reflection coating.

This work was carried out in the framework of the FP7 project "Fast Track", funded by the EC under grant agreement No. 283501. The computer modelling code was developed (electrical part) by P. Chatterjee during projects funded by MNRE and DST, Government of India, and the optical part was added during her tenure as Marie Curie fellow at Ecole Polytechnique, Palaiseau, France.

\section{References}

1. R. Butté, R. Meaudre, M. Meaudre, S. Vignoli, C. Longeaud, J.P. Kleider, P. Roca i Cabarrocas, Phil. Mag. B 79, 1079 (1999)

2. P.P. Ray, P. Choudhuri, P. Chatterjee, Thin Solid Films 403-4, 275 (2002) 
3. Baojie Yan, Guozhen Yue, L. Sivec, J. Yang, Subhendu Guha, C.-S. Jiang, Appl. Phys. Lett. 99, 113512 (2011)

4. P. Roca i Cabarrocas, A. Fontcuberta i Morral, S. Lebib, Y. Poissant, Pure Appl. Chem. 74, 359 (2002)

5. J.P. Kleider, C. Longeaud, M. Gauthier, M. Meaudre, R. Meaudre, R. Butté, S. Vignoli, P. Roca i Cabarrocas, Appl. Phys. Lett. 75, 3351 (1999)

6. P. St'ahel, S. Hamma, P. Sladek, P. Roca i Cabarrocas, J. Non-Cryst. Solids 227-230, 276 (1998)

7. P. Roca i Cabarrocas, Mater. Res. Soc. Symp. Proc. 507, 855 (1998)

8. A. Fontcuberta i Morral, R. Brenot, E.A.G. Hamers, R. Vanderhaghen, P. Roca i Cabarrocas, J. Non-Cryst. Solids 266-269, 48 (2000)

9. E.A. Schiff, J. Non-Cryst. Solids 352, 1087 (2006)

10. M. Brinza, G. Adriaenssens, P. Roca i Cabarrocas, Thin Solid Films 427, 123 (2003)

11. Y. Poissant, P. Chatterjee, P. Roca i Cabarrocas, J. Appl. Phys. 94, 7305 (2003)

12. K.-H. Kim, E.V. Johnson, A. Abramov, P. Roca i Cabarrocas, Sol. Energy Mater. Sol. Cells 105, 208 (2012)

13. N. Palit, P. Chatterjee, J. Appl. Phys. 86, 6879 (1999)

14. W. Ma, T. Saida, C.C. Lim, S. Aoyama, H. Okamoto, Y. Hamakawa, in Proceedings of the First World Conference on Photovoltaic Solar Energy Conversion, Hawaii (IEEE, New York, 1994), p. 117

15. X. Xu, J. Yang, A. Banerjee, S. Guha, K. Vasanth, S. Wagner, Appl. Phys. Lett. 67, 2323 (1995)

16. Z.Y. Wu, J.M. Siefert, B. Equer, in Proc. 10th EU PVSEC, Lisbon, Portugal, 1991, p. 953.

17. P.D. Veneri, L.V. Mercaldo, I. Usatii, Appl. Phys. Lett. 97, $023512(2010)$

18. A. Lambertz, F. Finger, R.E.I. Schropp, U. Rau, V. Smirnov, Prog. Photovolt.: Res. Appl. 23, 939 (2015)
19. K.-H. Kim, S. Kasouit, E.V. Johnson, P. Roca i Cabarrocas, Sol. Energy Mater. Sol. Cells 119, 124 (2013)

20. P. Roca i Cabarrocas, J.B. Chévrier, J. Huc, A. Lloret, J.Y. Parey, J.P.M. Schmitt, J. Vac. Sci. Technol. A 9, 2331 (1991)

21. Y.M. Soro, A. Abramov, M.E. Gueunier-Ferrat, E.V. Johnson, C. Longeaud, P. Roca i Cabarrocas, J.P. Kleider, J. Non-Cryst. Solids 354, 2092 (2008)

22. S. Vignoli, R. Meaudre, M. Meaudre, Phil. Mag. B 73, 261 (1996)

23. S.N. Abolmasov, H. Woo, R. Planques, J. Holovský, E.V. Johnson, A. Purkrt, P. Roca i Cabarrocas, Eur. Phys. J. Photovolt. 5, 55206 (2014)

24. P. Chatterjee, M. Favre, F. Leblanc, J. Perrin, Mater. Res. Soc. Symp. Proc. 426, 593 (1996)

25. N. Palit, P. Chatterjee, Sol. Energy Mater. Sol. Cells 53, 235 (1998)

26. Madhumita Nath, P. Chatterjee, J. Damon-Lacoste, P. Roca i Cabarrocas, J. Appl. Phys. 103, 034506 (2008)

27. P. Chatterjee, J. Appl. Phys. 76, 1301 (1994)

28. P. Chatterjee, J. Appl. Phys. 79, 7339 (1996)

29. P.J. McElheny, J.K. Arch, H.-S. Lin, S.J. Fonash, J. Appl. Phys. 64, 1254 (1988)

30. R. Stangl, M. Kriegel, K. v. Maydell, L. Korte, M. Schmidt, W. Fuhs, in Conference record 31st IEEE Photovoltaic Specialists Conference, 2005, p. 1556

31. R. Varache, J.P. Kleider, W. Favre, L. Korte, J. Appl. Phys. 112, 123717 (2012)

32. M.J. Powell, S.C. Deane, Phys. Rev. B 48, 10815 (1993)

33. M.J. Powell, S.C. Deane, Phys. Rev. B 53, 10121 (1996)

34. V. Halpern, Phil. Mag. B 54, 473 (1986)

35. C. Longeaud, J.P. Kleider, Phys. Rev. B 48, 8715 (1993)

36. F. Leblanc, J. Perrin, J. Schmitt, J. Appl. Phys. 75, 1074 (1994)

Cite this article as: Sergey Abolmasov, Pere Roca i Cabarrocas, Parsathi Chatterjee, Towards $12 \%$ stabilised efficiency in single junction polymorphous silicon solar cells: experimental developments and model predictions, EPJ Photovoltaics 7, 70302 (2016). 